\title{
NanTroSEIZE Stage 1 expeditions: introduction and synthesis of key results ${ }^{1}$
}

\author{
Harold Tobin, ${ }^{2}$ Masataka Kinoshita, ${ }^{2}$ Juichiro Ashi, ${ }^{2}$ Siegfried Lallemant, ${ }^{2}$ Gaku Kimura, ${ }^{2}$ \\ Elizabeth Screaton, ${ }^{2}$ Moe Kyaw Thu, ${ }^{2}$ Hideki Masago, ${ }^{2}$ Daniel Curewitz, ${ }^{2}$ \\ and the Expedition 314/315/316 Scientists ${ }^{2}$
}

\section{Chapter contents}

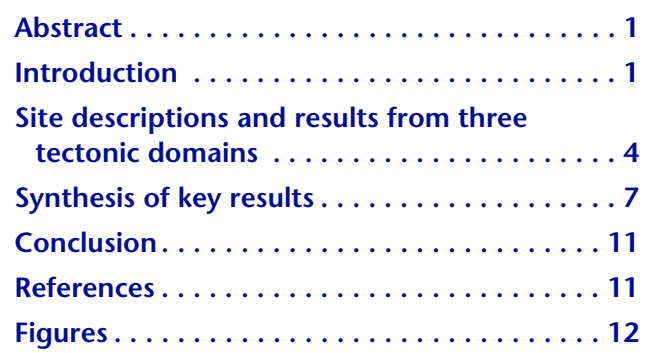

${ }^{1}$ Tobin, H., Kinoshita, M., Ashi, J., Lallemant, S., Kimura, G., Screaton, E., Moe, K.T., Masago, H., Curewitz, D., and the Expedition 314/315/316 Scientists, 2009. NanTroSEIZE Stage 1 expeditions: introduction and synthesis of key results. In Kinoshita, M., Tobin, H., Ashi, J., Kimura, G., Lallemant, S., Screaton, E.J., Curewitz, D., Masago, H., Moe, K.T., and the Expedition 314/ 315/316 Scientists, Proc. IODP, 314/315/316: Washington, DC (Integrated Ocean Drilling Program Management International, Inc.). doi:10.2204/iodp.proc.314315316.101.2009 2Expedition 314/315/316 Scientists' addresses. Correspondence author: htobin@wisc.edu

\section{Abstract}

Integrated Ocean Drilling Program Expeditions 314, 315, and 316 were carried out as a unified program of drilling collectively known as Stage 1 of the Nankai Trough Seismogenic Zone Experiment, a multistage complex drilling project. A transect of eight sites was selected for riserless drilling to target the frontal thrust region, midslope megasplay fault region, and Kumano forearc basin region. Two of these sites are preparatory pilot holes for planned deep riser drilling operations, whereas the others targeted fault zone material in the shallow, presumed aseismic zone. Expedition 314 was dedicated to in situ measurement of physical properties and borehole imaging through logging while drilling in holes dedicated to that purpose. Expedition 315 was devoted to core sampling and downhole temperature measurements at one site in the megasplay region and one site in the forearc basin. Expedition 316 targeted the frontal and out-of-sequence megasplay fault region in the mid-slope environment. Results on accretionary complex structure, lithology and age, physical properties, and state of stress, which are documented in full in the site chapters of this volume, are here synthesized across the expeditions.

\section{Introduction}

Integrated Ocean Drilling Program (IODP) Expeditions 314, 315, and 316 comprise the first of four stages of the multiyear project known as the Nankai Trough Seismogenic Zone Experiment (NanTroSEIZE), an effort that is unique in the history of scientific ocean drilling. The first stage of NanTroSEIZE drilling operations was conducted by the new riser-capable drilling vessel D/V Chikyu from September 2007 to February 2008. These expeditions were unique in scientific ocean drilling history, not only because all three expeditions carried out drilling for common overarching goals along a single transect but also because logging and coring operations for the same sites took place on separate expeditions for logistical and operational reasons.

Comprehensive reporting of the operations and results from each site are contained in the individual expedition summaries and site-specific chapters in this volume. This short summary chapter is intended to tie together the observations from the three expeditions and synthesize them into a common set of observations for the three major regions of study along the NanTroSEIZE transect: 
the frontal thrust area, the shallow tip of the megasplay fault and associated out-of-sequence (OOS) thrust sheet, and the Kumano forearc basin region (Figs. F1, F2). It is an inherently limited selection of the reported data; for comprehensive information on findings at each site, see the individual site chapters in this volume. In particular, the site summary figures from each expedition that appear as the first figure in each site chapter in this volume are not reproduced here, and the reader is encouraged to consult them.

This volume is organized according to the three operational expeditions as they took place; therefore, nearly all of the individual sites have separate chapter in both the Expedition 314 section, which reports the results of dedicated logging-while-drilling (LWD) holes, and in either the Expedition 315 or 316 sections, which report the results from the nearby coring holes at the same site locations. In IODP terminology, an individual site may have numerous holes separated by a few tens of meters.

\section{Background and objectives}

NanTroSEIZE is the first attempt to drill into, sample, and instrument the seismogenic portion of a plate boundary fault (also known as a megathrust) within a subduction zone. Access to the interior of active faults where in situ processes can be monitored and pristine fault zone materials can be sampled is of fundamental importance to the understanding of earthquake mechanics. As the December 2004 Sumatra earthquake and Indian Ocean tsunami so tragically demonstrated, large subduction earthquakes represent one of the greatest natural hazards on the planet. Accordingly, drilling into and instrumenting an active interplate seismogenic zone was identified as a very high priority in the IODP Initial Science Plan (2001).

The fundamental goal of the NanTroSEIZE science plan (Tobin and Kinoshita, 2006a) is the creation of a distributed observatory spanning the updip limit of seismogenic and tsunamigenic behavior at a location where great subduction earthquakes occur, thus allowing us to observe the behavior and properties of subduction megathrusts in both aseismic and seismogenic regions of the megathrust system. This involves drilling of key elements of the active plate boundary system at several locations off the Kii Peninsula of Japan, from the shallow onset of the plate interface to depths where earthquakes occur (Figs. F1, F2); Stage 1 drilling is the first effort toward this goal. At this location, the plate interface and active megasplay faults implicated in causing tsunamis are accessible to drilling within the region of coseismic rupture in the 1944 Tonankai M 8.2 earthquake. The most ambitious objective is to access and instrument the Nankai plate interface within the seismogenic zone through deep riser drilling, now planned for a later stage. The science plan entails sampling and long-term instrumentation of the inputs to the subduction conveyor belt and a major OOS fault system that splays from the plate interface to the surface (termed the "megasplay") and that may accommodate a major portion of coseismic and tsunamigenic slip and is thought to represent the main plate interface at a depth of $\sim 6 \mathrm{~km}$ (Moore et al.).

The primary objectives of NanTroSEIZE Stage 1 were to essentially complete the riserless coring and logging component of operations along the NanTroSEIZE transect; that is, all objectives besides the two planned deep riser drilled sites into the plate boundary fault systems (Tobin and Kinoshita, 2006a, 2006b). These objectives included drilling six target sites, including:

- The incoming sediment of Shikoku Basin and underlying oceanic crust (two sites),

- The frontal thrust system at the toe of the accretionary wedge,

- The mid-wedge megasplay fault system, and

- Approximately 1000-1400 m deep holes at the two sites planned for later deep penetration of the seismogenic zone faults, one of which was to have a subseafloor observatory.

In 2006, planning for Stage 1 operations included the three Chikyu expeditions plus two others scheduled for drilling using the R/V JOIDES Resolution. Changes in the availability of the JOIDES Resolution led to cancellation of those two additional expeditions, and the objectives of drilling the input sites and installing a borehole observatory had to be deferred to a later stage of NanTroSEIZE efforts. The overall objectives of the three expeditions that were carried out were to sample and characterize the sediments and relatively shallow levels of the major fault systems targeted for deep drilling in NanTroSEIZE to characterize fault properties outside the seismogenic zone and to "pilot" the planned deep riser holes as a preparatory step toward borehole engineering for drilling to unprecedented depths (Tobin and Kinoshita, 2006a).

The three linked expeditions carried out in Stage 1 on the Chikyu were:

- Expedition 314: LWD transect of the prism and forearc basin sites, 
- Expedition 315: coring and focused drilling of the megasplay fault thrust sheet and forearc basin, and

- Expedition 316: coring and focused drilling of the shallow $(<1000$ meters below seafloor [mbsf]) portions of the frontal thrust and megasplay fault zone.

To varying degrees, operational conditions and time constraints caused modifications to the original plans for all of these expeditions, but the majority of objectives were successfully accomplished. Seventyone scientists from 12 countries took part in the three expeditions as shipboard participants, and 33 holes were drilled at 8 sites to as deep as 1400 mbsf. Major accomplishments include:

- Successful core sampling of the presumed aseismic portions of major faults and near-fault environment at both the megasplay fault system and the frontal thrust area;

- In situ measurement of physical properties and borehole imaging with LWD instruments documenting present-day horizontal stress orientations through borehole breakout interpretation; and

- Documentation of the lithology, structural features, and age of sediments in and below the thrust sheets, fault zones, slope cover, and forearc basin.

Age determination of the forearc basin fill, slope cover, and sections overridden by thrusts in particular provides a framework for understanding the materials and processes in the seismogenic zone by providing information on the history of its development and evolution.

\section{Individual expedition objectives and Stage 1 strategy}

The Stage 1 plan for these three expeditions separated the downhole logging and vertical seismic profile (VSP) objectives for the sites from the coring and other downhole tool measurements. In order to efficiently utilize the expensive LWD logging tools and to preview drilling conditions at each planned coring site all the dedicated LWD measurement holes were slated for Expedition 314. Then the same sites were to be revisited during Expeditions 315 and 316, with Expedition 315 focused on the thrust sheet overlying the prominent branch of the megasplay fault system (Fig. F3) at what became Site C0001 (planned for later deep riser drilling) and Expedition 316 focused on thrust fault and wall rock zone sampling at the megasplay fault tip and frontal thrust region (ultimately Sites C0004 and C0008 and Sites C0006 and C0007, respectively). Because of unforeseen drilling challenges and a resulting need to in- voke contingency plans, not all sites that were logged were also cored, and vice versa.

\section{Expedition 314}

The original goals of Expedition 314 were to obtain a comprehensive suite of geophysical logs and other downhole measurements at sites (Figs. F2, F3) along the NanTroSEIZE transect using state-of the-art LWD technology. These six sites were designed to accomplish the principal goals of the NanTroSEIZE science plan, including documenting the material inputs to the subduction conveyor (fluid, solids, and heat), the properties of major thrust faults and their wall rocks at depths shallower than $\sim 1.4 \mathrm{~km}$, and the geology of the accretionary prism and overlying slope basin sediments (Tobin and Kinoshita, 2006a; Kinoshita et al., 2006). Four of the six planned sites were in fact drilled and logged during Expedition 314 in all three tectonic regions, but multiple attempts to find sites to drill into the megasplay fault zone resulted in six numbered sites drilled in total. Four of those were subsequently cored during Expeditions 315 and 316, as well as two additional sites that had not been logged during Expedition 314 (Sites C0007 and C0008).

Logging included the measurement of natural gamma radiation, azimuthal gamma ray density, neutron porosity, full waveform sonic velocity, azimuthal resistivity imaging, zero-offset VSP, ultrasonic caliper, and annular fluid pressure, though not all logs in this suite were collected at all sites. The overarching objective of the LWD program was to provide borehole data to be used in conjunction with cores to document the geology, physical properties, mechanical state, fluid content, and stress conditions at the drilling site locations. LWD operations were for the most part successful; however, mechanical failures caused loss of some logs at two sites, and the lost drill string with a full suite of LWD tools at Site C0003 meant that porosity and density data using the radioactive source tools could not be collected at subsequently drilled Sites C0004 and C0006.

\section{Expedition 315}

Expedition 315 was planned to focus all its efforts on riserless drilling, coring, downhole measurement, and casing installation over the upper $1000 \mathrm{~m}$ of Site C0001, planned as the pilot site for the first riser drilling in Stage 2. During Expedition 314 LWD was carried out successfully to $976 \mathrm{~m}$ LWD depth below seafloor (LSF), but difficult hole conditions were encountered, including an interval of high drill string torque caused by apparent borehole caving, enlargement, and partial collapse at $\sim 460-540 \mathrm{~m} \mathrm{LSF}$, an in- 
terval that became known as "the sticky zone." In attempts to core Site C0001 in multiple holes during Expedition 315, drilling did not advance beyond 458 $\mathrm{m}$ CSF. Coring results document the age and makeup of the deformed megasplay thrust sheet and overlying slope apron deposits, as well as structural features and inferences on evolution of the stress state. Installation of surface conductor casing and a 20 inch casing to 700 mbsf was a major objective in preparation for future riser drilling at this site. However, given the challenging drilling conditions and the strong Kuroshio Current, a mid-expedition decision was made to forego both casing and further attempts at deeper coring at this site, freeing up time for substantial coring operations at Site C0002 in the Kumano forearc basin (Fig. F3). In order to meet high-priority NanTroSEIZE objectives of sampling the lower Kumano Basin and underlying prism rocks, a hole was washed down to $500 \mathrm{mbsf}$ and then cored from that depth to $1057 \mathrm{~m} \mathrm{CSF}$. In the waning days of the expedition, two additional holes cored the interval from 0 to $200 \mathrm{~m} \mathrm{CSF}$ at the same site. Results indicate the nature and age of accretion of the prism rocks and the history of formation and filling of the forearc basin.

\section{Expedition 316}

Expedition 316 was designed to evaluate the deformation, inferred depth of detachment, structural partitioning, fault zone physical characteristics, and fluid flow at the frontal thrust and shallow portion of the megasplay fault system. To accomplish these objectives, drilling was conducted at two sites in the megasplay region, one within the fault zone (Site C0004) and one in the slope basin seaward of the megasplay (Site C0008). Two sites were drilled in the frontal thrust region (Sites C0006 and C0007). At Site C0006, several fault zones within the prism were penetrated before drilling was stopped short of the frontal thrust itself because of poor conditions in the borehole. The plate boundary frontal thrust was successfully drilled at Site C0007, and thrust fault material ranging from breccia to fault gouge was successfully recovered. The footwall proved to be remarkably coarse grained, as it was dominated by sand and gravel trench-axial channel facies deposit, and core recovery was very poor in this interval.

\section{Site descriptions and results from three tectonic domains}

In this section, the principal results of drilling in each of the three tectonic regions are synthesized, beginning with the two sites drilled in the frontal thrust region, moving to the four sites in the mid- slope megasplay fault zone region, and finally moving to the single Kumano Basin site.

\section{Frontal thrust region (Sites $\mathrm{C0006}$ and C0007)}

Drilling at Sites C0006 (Expeditions 314 and 316) and C0007 (Expedition 316 only) allowed examination of the frontal thrust region (Fig. F4). In Hole C0006B, LWD operations successfully drilled and logged to $885 \mathrm{~m}$ LSF, crossing the probable frontal thrust zone in the interval between 657 and $711 \mathrm{~m}$ LSF. The ambiguity exists because of the complex seismic reflectivity character, including apparent trench-fill channel deposit packages, and the lack of coring to this depth to reveal the detailed structure. The $657 \mathrm{~m}$ interval is a zone with an apparent high degree of fracturing/brecciation based on LWD resistivity images and may be a candidate for the frontal thrust. During Expedition 316, drilling in Holes C0006E and C0006F did not penetrate to this depth before drilling was stopped because of poor conditions and extremely poor core recovery. In the interval beneath $711 \mathrm{~m}$ LSF, however, gamma and resistivity logs indicate that the section is sand dominated. The apparently equivalent units at Site C0007 exhibit massive coarse dark gray sands.

The plate boundary frontal thrust was successfully cored nearby at Site C0007, and thrust fault material ranging from breccia to fault gouge was recovered. The lowermost part of fault Zone 3 at $438 \mathrm{~m}$ core depth below seafloor (CSF) is intensely brecciated into fragments $\sim 1-10 \mathrm{~mm}$ in size (Fig. F5). This 29 $\mathrm{cm}$ thick breccia shows a foliated aspect from an anastomosing network of polished and striated surfaces. At the base of this zone, a $2 \mathrm{~mm}$ thick dark layer sharply separates intensely brecciated hemipelagic mudstone above from unbroken hemipelagic mudstone and ash below. There is a biostratigraphic age reversal as well. These features indicate that the thin dark layer most likely represents extreme localization of slip associated with thrust faulting.

As a result of coring at the two sites, several new aspects of the accretion/subduction system were revealed. The upper accretionary prism is composed of coarse terrigenous sediments, including gravel-dominated and mud-dominated lithologies in the upper and lower parts of the accretionary wedge, respectively. They likely represent trench wedge to slope sediments and hemipelagic Shikoku Basin sediments, respectively; however, that interpretation must be confirmed by more detailed onshore analysis and results of planned drilling of sediments on the incoming plate. The modern trench wedge is composed of channel-filling deposits that are currently underthrusting beneath the toe of the accre- 
tionary prism. The plate boundary frontal thrust zone at $418-438 \mathrm{~m}$ CSF is located in a stratigraphic package of upper Miocene mud, which appears to be similar to the Shikoku Basin facies that hosts the décollement in the Muroto and Ashizuri transects (Moore, Taira, Klaus, et al., 2001).

Lithologic Unit I sediments at Site C0006 are interpreted to represent a transition from trench to slope deposition; thus, the Unit I/II boundary records the uplift of trench material into the prism. Unit I sediments are younger than or the same age as sediments filling the basin behind the thrust. The age of the boundary is $\sim 0.9$ Ma. Taking into account the relative plate motion velocity between the overriding Japanese islands and the Philippine Sea plate $(\sim 4$ $\mathrm{cm} / \mathrm{y}$ [Seno et al., 1993]) the relative slip distance has to be $\sim 40 \mathrm{~km}$. No frontal accretion during this period means that the plate boundary frontal thrust has large displacement (total relative motion minus horizontal shortening of the accretionary prism). How such a large amount of slip has concentrated within the fault zone and how the evolution of the fault zone has affected the characteristic features in this region are two of the important issues of postexpedition research.

The accretionary prism in the frontal thrust region is deformed by thrusting, as visible on the seismic profiles (Figs. F3, F4; also Moore et al.). Most of the thrusts inferred from the seismic profiles and LWD data were confirmed through age reversals, fault zones sampled in cores, and repetition of specific strata, but some additional faults were also defined during Expedition 316 drilling. Chemical analysis of interstitial fluid and microbial habitat around most of these "intraprism" thrusts do not indicate any signal of active fluid flow.

In contrast to such intraprism thrusts, many normal faults are developed at the core scale and appear to be the youngest deformation feature. Clear slopeparallel mass sliding is observed from the submarine topography, seismic profiles, and shallow cores. These facts suggest that the taper angle of the prism is presently above the critical wedge taper angle and is unstable; there is evidence that the system is currently in a period of collapse.

Porosity data suggest that a considerable thickness of material has been eroded or otherwise removed from the surface at Sites C0006 and C0007. Porosity is quite low at shallow depths below the surface, reaching $48 \%$ at 5 and $34 \mathrm{~m} \mathrm{CSF}$ at Sites C0006 and C0007, respectively. In contrast, porosity does not decrease to $<50 \%$ until $\sim 150$ or $\sim 200 \mathrm{~m}$ CSF, respectively, at other sites on the Stage 1 transect.

\section{Megasplay fault region (Sites C0001, C0003, C0004, and C0008)}

The OOS megasplay fault zone branches into a number of individual splays as it enters the upper few kilometers of the subsurface (Fig. F3; also Moore et al.). A series of sites targeted the thrust sheet, fault zone, and footwall of the lower of these branches, which was judged to be the most active and most significant of the seismically imaged splays (Tobin and Kinoshita, 2006b; Moore et al.). Site C0001 was chronologically first in drilling and targeted only the thrust sheet in the most landward position, not the underlying fault itself. The fault zone was judged too deep ( 2000 mbsf) to access with riserless drilling at this site.

\section{Site $\mathrm{C} 0001$}

For NanTroSEIZE Stage 2, $3.5 \mathrm{~km}$ riser drilling was planned at Site C0001, located at a small bench on the hanging wall of the main branch of the megasplay fault (Fig. F6) where a small slope basin with coherent layered reflectors has developed, overlying a more seismically chaotic thrust sheet above the splay fault. In Stage 1, pilot-scale drilling of the uppermost $1000 \mathrm{~m}$ at this site was executed to test conditions for riser drilling and set the surface casing for later efforts. We first drilled a LWD-only hole at this site, achieving $976 \mathrm{~m}$ of penetration (only $24 \mathrm{~m}$ short of the planned depth and sufficient to achieve all logging objectives). Logging results suggest that the sediments of the hanging wall thrust sheet are primarily muds and mudstones with some silty to sandy (or ash bearing) sediments overlain by $\sim 200 \mathrm{~m}$ of hemipelagic slope deposits. Resistivity imaging suggests widespread fracturing and variable bedding orientation, which in turn suggests strong deformation. Subsequent coring at this site during Expedition 315 confirmed and greatly added to these observations. The cored interval extends to 458 $\mathrm{m}$ CSF including the slope basin (lithologic Unit I) and the top $\sim 250 \mathrm{~m}$ of the underlying accretionary prism (Unit II). The slope basin is composed mainly of Quaternary to late Pliocene silty clay and clayey silt with intercalations of volcanic ash. The boundary between Units I and II, identified at $207.17 \mathrm{~m} \mathrm{CSF}$, is an unconformity located immediately below a thick sand layer. Unit II is composed of mud-dominated sediments of late Pliocene to late Miocene age. Structural style and inferred stress state vary widely across a deformed zone between 220 and 230 m CSF. Normal faults indicating northeast-southwest extension are dominant above this zone; however, a few thrust faults dipping at $50^{\circ}$ were encountered just above the deformed zone. These thrust faults are consistent with a northwest-southeast 
shortening subparallel to the direction of plate convergence. On the other hand, many thrust and strike-slip faults and a normal fault are found below the $220 \mathrm{~m}$ CSF deformed zone. The geometry and kinematics of planar structures display great variation. Kinematic solutions computed from normal and thrust faults are consistent with northeast-southwest extension and northwest-southeast shortening, respectively. Interstitial water geochemistry data show interesting trends for most elements; however, changes in these trends do not necessarily correspond to unit boundaries. Methane and ethane concentrations and their ratio $\left(\mathrm{C}_{1} / \mathrm{C}_{2}\right)$ decrease with depth to $100 \mathrm{~m}$ CSF and remain constant to the base of lithologic Unit I. The increase of methane concentrations and $\mathrm{C}_{1} / \mathrm{C}_{2}$ ratios in Unit II indicate the contribution of biogenic methane. Total organic carbon and calcium carbonate decrease monotonously to the base of Unit I and remain low throughout Unit II. Physical properties also show a clear break at the boundary between Units I and II. Porosity generally decreases downhole within each unit; however, there is a step across the unit boundary with higher porosity below the boundary. Below this, the trend of decreasing porosity with depth resumes.

\section{Site $\mathrm{C0003}$}

This site was intended to begin the downdip transect of the megasplay fault system by sampling a relatively shallow, presumably aseismogenic point on the fault zone at $~ 800$ mbsf. Unfortunately, we encountered very difficult drilling conditions at Site C0003, such as especially pronounced caving and washout of likely fault zones and possibly sandy intervals, which caused the drill string to become irretrievably stuck before reaching the primary objective. We were unable to recover the bottom-hole assembly with the LWD tool string and $\sim 200 \mathrm{~m}$ of drill collars at this site. Nevertheless, real-time data transmission provided substantial logging data from the seafloor to $\sim 530 \mathrm{~m}$ LWD depth below seafloor (LSF). No further drilling or coring was attempted here; we instead moved to Site C0004 (see next section).

Consistent with the other mid-slope sites, the lithology at Site C0003 is apparently composed of relatively coarse silt-sand and hemipelagic mud in the shallowest portion underlain by more clay rich, generally homogeneous muddy deposits interrupted by prominent zones of washouts interpreted as brecciated intervals, indicating likely faults. The seismic reflection imaging shows that this site was drilled into a series of at least three individual thrust sheets within the hanging wall of the megasplay fault system (Fig. F7). Therefore, major washout zones identified in logs at 240 and $420-450 \mathrm{~m}$ LSF are likely to be strongly brecciated damage zones from subsidiary thrusts, analogous to fault breccia recovered in core at other sites (see for example the "Expedition 316 Site C0004" and "Expedition 316 Site C0007" chapters).

The seismic interpretation is consistent with substantial uplift of the thrust sheet bringing older and more deeply buried accretionary prism rocks to within $500 \mathrm{~m}$ of the seafloor. Log density data show relatively constant and high values for this depth, suggesting that anomalously well-indurated rocks make up the thrust sheet. When the broken section of drill pipe was recovered to the rig floor after loss of the LWD string, it was plugged with numerous large chunks (as large as $5-8 \mathrm{~cm}$ in diameter) of cavings that had come from an unknown position in the hole. This material had a nannofossil age of late Miocene (5.5-7.2 Ma), bulk density of $2.1 \mathrm{~g} / \mathrm{cm}^{3}$, and $P$-wave velocity of $\sim 2.1 \mathrm{~km} / \mathrm{s}$, also consistent with the thrust sheet rocks having been uplifted from greater depth within the accretionary complex.

\section{Site C0004}

Site C0004 is located seaward of Sites C0001 and C0003 (Fig. F6) and targeted the prominent splay fault reflector at $\sim 300$ mbsf. The overlying thrust sheet, megasplay fault zone, and $\sim 100 \mathrm{~m}$ of the footwall sediments were successfully drilled with both LWD logging (Expedition 314) and coring (Expedition 316). Drilling at this site also examined the youngest sediments on the slope overlying the accretionary prism, which consist of slowly deposited hemipelagic marine sediments and redeposited material from upslope. This redeposited material provides information about past slope failures, which may be related to past megasplay movement, earthquakes, and tsunamigenesis. The top of the prism corresponds to a prominent unconformity (age gap = $\sim 1$ m.y.) that contains pyrite and other mineralization. Structural observations of core material from the fault zone and two age reversals suggested by nannofossils indicate a complex history of deformation. Sediments under the fault zone were sampled to understand their deformation, consolidation, and fluid flow history. Further results and discussion of Site C0004 are synthesized in "Synthesis of key results."

\section{Site C0008}

Drilling at Site C0008 targeted the slope basin seaward of the megasplay fault (Fig. F6) as a complement to Site C0004, which is $\sim 1 \mathrm{~km}$ farther landward. This basin records the history of fault movement. Sediments are Pleistocene to late Pliocene hemipelagic silts and clays with ashes. Several 
gravelly sequences interpreted as indicative of mass transport complexes were identified. Sediments of the slope basin at Site C0008 provide a "reference site" for the sediments underthrust beneath the megasplay fault. Comparison of the interval 190-200 m CSF in Hole C0008A with an average porosity of 50\% and the correlated interval 320-330 m CSF in Hole C0004D with an average porosity of $43 \%$ suggests the sediments are dewatering during underthrusting. Evidence for lateral flow is provided by $C_{1} / C_{2}$ ratios at Site $\mathrm{C} 0008$ that are slightly lower than expected for biogenic production at the estimated in situ temperature. Lateral flow along sand layers could transmit fluids from where the temperature is higher because of greater burial beneath the splay fault, driving fluids out along permeable sandy layers.

\section{Kumano forearc basin region (Site C0002)}

Site C0002 sampled the Kumano forearc basin and underlying old accretionary prism material. LWD drilling was very successful here, with a single hole achieving $1401 \mathrm{~m}$ penetration, making it the deepest LWD hole in scientific ocean drilling to date. Approximately $940 \mathrm{~m}$ of drilling was through the sediments of the Kumano forearc basin, and the lower $\sim 460 \mathrm{~m}$ accessed the underlying rocks interpreted to be the accretionary prism formed through earlier frontal accretion.

This site is slated to be the centerpiece of the NanTroSEIZE project, with $6 \mathrm{~km}$ or more drilling planned to access the plate boundary at seismogenic zone depths in a later stage. Understanding the physical properties and documenting tectonic processes and lithology in the hanging wall of the plate boundary here were therefore important goals of Stage 1 drilling, not least because of the need for high-quality borehole engineering parameters to plan riser drilling. Scientifically, the hole records the timing and history of the megasplay system in the formation and filling of the Kumano Basin and was used to document the present-day stress regime in this portion of the margin (see "Synthesis of key results").

During Expedition 315, Site C0002 was drilled again in two holes to $1057 \mathrm{~m}$ CSF with coring of the intervals from 0 to $204 \mathrm{~m} \mathrm{CSF}$ and 475 to $1057 \mathrm{~m} \mathrm{CSF}$. We cored across the basal unconformity of the Kumano forearc basin at $\sim 922 \mathrm{~m} \mathrm{CSF}$ and cored another 135 $\mathrm{m}$ into the accretionary prism. The forearc basin sequence is divided into two units based on lithofacies. All units are dominated by mud and mudstone; however, lithologic Units I and II contain more sand and silt intercalation and have a much faster sedimentation rate. The age ranges from Quaternary to late Miocene. Underlying accretionary prism materi- als contain moderately more lithified and much more deformed sediments.

The Kumano Basin is a young feature (mostly Quaternary) with a high sedimentation rate $(>800 \mathrm{~m} /$ m.y.) overlying a late Miocene (5-6 Ma) accretionary prism, much younger than most of the Tertiary Shimanto belt outcropping onland. Biostratigraphic data show that the transition from Pliocene to late Miocene strata occurs as a marked age gap around $922 \mathrm{~m} \mathrm{CSF}, \sim 15 \mathrm{~m}$ above the log-lithostratigraphic unit boundary defined during Expedition 314 based on LWD data.

\section{Synthesis of key results}

\section{Lithology, structure, and recent activity of megasplay fault and associated thrust sheet (Sites C0001, C0004, and C0008)}

Based on seismic and tsunami inversion studies combined with seismic reflection research, various theories have suggested that the splay fault system in this area slipped during the 1944 Tonankai M 8.2 earthquake to generate the observed tsunami (Baba et al., 2006; Park et al., 2002). Moore et al. (2007) also suggest recent historical and geological accumulation of displacement along the fault on the basis of three-dimensional (3-D) seismic reflection investigation. The age reversal from Pliocene to Pleistocene documented beneath the splay fault during Expedition 316 is consistent with geologically recent activity. However, age resolution is of course insufficient to document historical-scale fault activity.

The "Expedition 316 Site C0004" chapter discusses the evidence for recent activity of the splay fault. To summarize: the splay fault clearly thrusts the hanging wall prism over younger slope sediments in the footwall; however, the youngest slope sediments that cover the fault appear not to be cut by the fault. In addition, the lack of a slope break on the seafloor above the fault might also suggest that this splay fault is presently not active but ceased activity in the recent past. However, shipboard results provide support for the alternate interpretation that the splay fault is active as a blind thrust, in which the tip of the fault has not propagated to the surface but remains buried. Slip on deeper levels of the fault zone are expressed by some combination of folding and layer-parallel slip in the shallow slope sediments draping the uppermost portion of the megasplay, as well as the possible triggering of marine slump or slide deposits. Drilling results at Site C0004 indicate that the shallowest cover sediments above the hanging wall wedge are composed of repeated mass transport complexes associated with repeated slope col- 
lapses and rip-up debris generation. Pleistocene cover sediments dip steeply approximately parallel to the slope and are cut by numerous normal faults.

Despite inferences of recent activity on the splay fault system, no porosity inversion is observed beneath the splay fault; this contrasts with previous results from the décollement of the Muroto transect (Screaton et al., 2002), in which a clear porosity inversion across the fault likely reflects fluid overpressure. Unlike the Muroto transect décollement, the splay fault system observed at Site $\mathrm{C0004}$ has permeable pathways for dewatering provided by the observed sand and coarse ash layers.

Sediments of the slope basin at Site C0008 provide a "reference site" for the sediments underthrust beneath the megasplay fault. Comparison of the interval 190-200 m CSF in Hole C0008A with an average porosity of $50 \%$ and the correlated interval 320-330 $\mathrm{m}$ CSF in Hole C0004D with an average porosity of $43 \%$ suggests the sediments are dewatering during underthrusting. Evidence for lateral flow is provided by $\mathrm{C}_{1} / \mathrm{C}_{2}$ ratios at Site $\mathrm{C} 0008$ that are slightly lower than expected for biogenic production at the estimated in situ temperature. Lateral flow along sand layers could transmit fluids from where the temperature is higher because of greater burial underneath the splay fault.

These sand layers are truncated at a normal fault drilled in Hole C0008C, where surficial material has slid downward. Hole C0008C structural descriptions document normal faults within the sediments at $\sim 40$ $\mathrm{m}$ CSF. Lateral transmission of fluids from areas with thicker to thinner overburden has previously been suggested as a mechanism for enhancing slope failure (Dugan and Flemings, 2000). As a result, splay fault movement could produce slope failures through seaward propagation of pore pressures from the footwall in addition to oversteepening of the hanging wall. Postcruise examination of lithologic evidence, structural data, and physical properties will help assess the interaction between splay fault movement and slope failures.

Two steps of age reversal are tentatively recognized across the splay fault zone; this evidence suggests that fault-bounded lithologic Unit III at Site C0004 is a sliverlike unit coming up from a much deeper setting. The lithology of the slope sediments and the old accretionary prism in Hole C0008A suggests that one of the possible sources for the Unit III "sliver" at Site C0004 is the lowermost slope sediments beneath the Pleistocene and late Pliocene slope sediments. In this case, displacement along the splay fault, especially the lower boundary fault beneath Unit III, might be more than a couple of kilometers. Interestingly, porosity within this lithologic unit is slightly higher than expected relative to trends observed in overlying material. If these materials have been brought up from depth, they either never had an opportunity to consolidate or have subsequently had considerable opening of porosity by microfractures in this fault sliver.

\section{Age of cover sequence and uplifted accretionary prism units}

Rocks of the thrust sheet below $500 \mathrm{~m}$ LSF at Site C0001 and also of the cavings sampled at Site C0003 are anomalously dense relative to their present depth of burial and show high sonic/seismic velocity, indicating relatively advanced lithification. This suggests significant uplift and exhumation along the splay thrust. These inferences are consistent with the age determinations made on cores, showing that this thrust sheet contains rocks several millions of years old, in contrast to the immediately overlying slope deposits. Notably, thrust sheet material drilled at Site C0004 is substantially younger than the analogous material at Site C0001, C0002, or C0003 (Fig. F6), suggesting that the megasplay thrust sheet contains internal structural imbrication and has incorporated material progressively as it advanced.

At all of the sites landward of the frontal thrust area, units interpreted to be uplifted section that was frontally accreted to the prism are covered by varying amounts of slope drape. In the case of Site C0002, this slope drape is in turn covered with the thick, dominantly Pleistocene Kumano forearc basin section. Biostratigraphy (predominantly by nannofossil zones) and magnetostratigraphy define the ages of sediments above and below these boundaries, which also record time gaps of various durations between the prism section and cover.

In the frontal thrust region at Site C0006, the transition from uplifted trench sediments into the overlying slope apron cover sediments is dated to 0.436$0.78 \mathrm{Ma}$, presumably recording the timing of initial frontal thrust activity. Only $27 \mathrm{~m}$ of younger slope cover overlies this boundary, implying potential removal of young deposits through slumping or mass wasting.

Moving to the mid-slope megasplay fault region, the oldest sediment at the base of the slope cover at Site C0004 was dated at $1.46 \mathrm{Ma}$, unconformably resting on sediments that are 1.1. m.y. older than that. Just a short distance landward at Site C0001, in the same apparent overall thrust complex (Figs. F3, F6), the age of the base of the slope apron is $2.0 \mathrm{Ma}$, which is 
substantially older than at Site C0004, and rests on a nearly $4 \mathrm{Ma}$ accreted section. Ten kilometers further landward in the Kumano Basin at Site C0002, the slope apron lies on top of the accreted complex at a depositional age of $3.79 \mathrm{Ma}$, resting on $>5$ Ma sediments in the accreted section. This landward progression of successively older dates marking the uplift and surface exposure of Shikoku Basin sediments is consistent with progressive growth of the accretionary prism through late Miocene to Quaternary time.

Furthermore, the slope apron at Site C0002 accumulated very slowly until $\sim 1.5 \mathrm{Ma}$, then $>800 \mathrm{~m}$ of forearc basin turbidites accumulated rapidly. The implication of this latter observation is that the onset of splay fault uplift of a pronounced outer arc high and/or capture of a significant turbidite sediment source for the basin was abrupt in the early Pleistocene. The youngest dated sediment in the uppermost $10 \mathrm{~m}$ at Site C0004 is several hundred thousand years old, and nannofossil Zone NN21 was not identified, raising the possibility that more recent sediments have been removed through slumping and mass transport processes.

\section{Indicators of stress regime}

\section{Borehole breakouts and present-day stress orientations}

Borehole breakouts were observed at all four sites for which we have imaging data and show very systematic orientations (Fig. F8). In a vertical borehole, the orientation of breakouts, or borehole wall failures upon drilling, is a well-established indicator of the orientation of the horizontal maximum principal stress in the present-day stress field extant at the location of the hole (Zoback et al., 2003). Less frequently, drilling-induced tensile fractures were observed, primarily at Site C0001 in the splay fault thrust sheet. Breakout orientations at Sites C0001, C0004, and C0006 all indicate northwest-southeast azimuths of the maximum horizontal principal stress $\left(S_{\mathrm{H} \max }\right)$ (Fig. F9). At Site C0001, $S_{\mathrm{H} \max }=336^{\circ}$; at Site C0004, $S_{\mathrm{H} \max }=320^{\circ}$; and at Site C0006, $S_{\mathrm{H} \max }=$ $330^{\circ}$. In the thrust-dominated tectonic environment, this is consistent with trench-normal shortening, although strike-slip and/or normal faulting stress states are also permissible (see next section).

Variations of the breakout orientation among these three sites of as much as $10^{\circ}-16^{\circ}$ are statistically significant and may be caused by local structure influencing local stress orientation. In particular, surface slope direction varies and slope related gravitational stresses might influence these values. Nevertheless, the overall consistency among these three distinct sites suggests that these stresses record the regional tectonic control. In addition, all of these $S_{\text {Hmax }}$ orientations deviate from the far-field plate motion vectors based on Global Positioning System results (Heki, 2007) and global plate motion models (Seno et al., 1993), implying some strain partitioning between convergence and strike-slip motions.

In contrast, at Site C0002 in the Kumano Basin the orientation of $S_{\mathrm{Hmax}}$ is northeast-southwest at $134^{\circ}$, or very nearly perpendicular to that in the more trenchward sites (Figs. F8, F9). This is consistent with a normal faulting stress state that extends through the basin section, which in fact exhibits numerous normal faults, and also in at least the upper $400 \mathrm{~m}$ of the underlying older accretionary prism section. This contrast between the outer accretionary prism and the forearc basin region, including the buried prism rocks beneath, suggests that the tectonic stress magnitudes differ markedly in the upper part of the prism at sites just a few kilometers apart along the transect. The stress regimes are distinct. Furthermore, gravitationally driven extension may be important above the megasplay where the outer arc high has been uplifted. Implications of these data will be explored in postexpedition research to understand the mechanical state of the prism and basins.

\section{Paleostress from core-based structural data}

Core-scale structures can be used to infer paleostress regimes. Cores drilled during Expedition 315 in Holes C0002C and C0002D (Kumano Basin site) show small-scale structures consistent with the interpretation that the present-day stress field is extensional and directed northeast-southwest. This agrees very well with the interpretation of breakout data for the present-day stress field (see the "Expedition 315 Site C0002" chapter). Fault analyses from that site show the following time evolution of the stress field:

1. First phase of northwest-southeast shortening by thrust faulting and possibly strike-slip faulting,

2. Second phase of northeast-southwest extension by normal faulting, and

3. Third phase of north-south extension by normal faulting consistent with the main normal faults seen in the 3-D seismic lines. This last phase correlates with the borehole breakout observations.

In the minor structures observed in the megasplay thrust sheet at Site C0001 and at the frontal thrust at Site C0006, both reverse and normal faults were documented, with minor strike-slip as well. In general, there is an overall indication at both of these sites that the youngest and/or most numerous small faults are normal and record extensional conditions (see the "Expedition 315 Site C0001" and "Expedi- 
tion 316 Site C0006" chapters). In the case of Site C0006, this was interpreted by the shipboard party as evidence of geologically recent collapse of an oversteepened frontal wedge (see the "Expedition 316 Site C0006" chapter). At Site C0004 in the front of the megasplay thrust sheet, by contrast, normal faults were not prominent except in a thin and shallow slope cover sequence from 0 to $78 \mathrm{mbsf}$, and reverse faults dominate, consistent in orientation with the breakout data for a reverse faulting stress state.

Site C0001 shows reverse faulting beneath the slope cover, but this is overprinted by normal faults recording northeast-southwest directed extension, even in the thrust sheet. The paleostress regime inferred from these small faults at Site C0001 is consistent with a maximum horizontal stress perpendicular to the margin as inferred during Expedition 314 from borehole breakouts but shows a permutation of the maximum principal stress between the upper $200 \mathrm{~m}$ (extension parallel to the margin, $\sigma_{1}$ vertical) and the deeper section (compression perpendicular to the margin, $\sigma_{1}$ horizontal). This can be explained by changes in the relative magnitude of the principal stresses without change of their orientations.

These results suggest an alternative interpretation of the borehole breakout data. $S_{\mathrm{H} \max }$ at Sites $\mathrm{C0001}$ and C0006 could represent the intermediate principal stress, consistent with an extensional stress state oriented perpendicular to the inferred compressional state. However, the Site C0004 observations favor the thrust state of stress. These inferences may not be in conflict if the three principal stresses differ only modestly at these shallow depths, and small changes in their relative magnitude can effect a "flip" in stress/faulting regime. Further analysis awaits postcruise efforts.

\section{Thermal regime}

Acquisition of a transect of good quality downhole temperature profiles and thermal conductivity data was an important part of Stage 1 drilling. Thermal regime has been hypothesized to be closely tied to fault stability criteria (e.g., Hyndman et al., 1995), and the prediction of temperature at plate boundary fault zone depths is dependent on well-defined heat flow and thermal properties. Prediction of temperature at deeper borehole depths is also crucial for future deep-well planning and the mechanical specifications of long-term borehole tools to be installed during NanTroSEIZE Stage 4 because operating temperature placed severe constraints on available tools.

Downhole temperature measurement using the advanced piston corer temperature tool and Davis-Villinger Temperature Probe was successfully conducted across the Stage 1 transect. For details of the data from each site, see the respective site chapters in the Expedition 315 and Expedition 316 reports. In general, good linear gradients indicative of predominantly conductive heat flow were found at all sites, with the exception of some depths at Site C0006.

From southeast to northwest (i.e., seaward to landward along the transect), the results are as follows. In the frontal thrust region at Site C0007, the thermal gradient is $42^{\circ} \mathrm{C} / \mathrm{km}$ (heat flow $=53 \mathrm{~mW} / \mathrm{m}^{2}$ ). At the nearby Site C0006, a thermal gradient of $27^{\circ} \mathrm{C} / \mathrm{km}$ (heat flow $=33 \mathrm{~mW} / \mathrm{m}^{2}$ ) was computed from six measurements for anomalously low values of both gradient and heat flow, relative to regional data and the other sites. Moving to the megasplay sites, the best fitting thermal gradients were $51^{\circ} \mathrm{C} / \mathrm{km}$ and $57^{\circ} \mathrm{C} / \mathrm{km}$ in Holes C0008A and C0008C, respectively. Very close by at Site $\mathrm{C0004}$ the measured gradient was $52^{\circ} \mathrm{C} / \mathrm{km}$. At Site C0001 the measured gradient was $44^{\circ} \mathrm{C} / \mathrm{km}$ (heat flow $=47 \mathrm{~mW} / \mathrm{m}^{2}$ ). Moving into Kumano Basin, the thermal gradient at Site C0002 was $43^{\circ} \mathrm{C} / \mathrm{km}$.

All of these gradients are consistently lower than those estimated from surface measurements (Kinoshita et al., 2008). The extremely low heat flow observed at frontal thrust Sites C0006 and C0007 might be related to stratigraphic or structural fluid pathways developed in this region, perhaps facilitating circulation of seawater down into the thrust sheet, though geochemical evidence of seawater circulation was not identified in pore water analyses at those sites.

\section{Gas hydrates and bottom-simulating reflector}

At Site C0002, a well-developed bottom-simulating reflector (BSR) is imaged in the seismic data, and LWD logs recorded comprehensive in situ information about the nature of this BSR (see the "Expedition 314 Site C0002" chapter). Resistivity logs showed a pattern of elevated resistivity background and spikes for $\sim 200 \mathrm{~m}$ above the BSR depth at $\sim 400$ $\mathrm{m}$ LSF. The gamma response indicated that the spikes are in especially sandy intervals as thick as 1-2 m, interpreted as the coarse basal beds in turbidite deposits. Sonic and resistivity responses are consistent with pore space in these sands being partially filled and "cemented" with gas hydrate. In contrast, similar sands below the BSR depth show no elevated resistivity response. In a zone $80 \mathrm{~m}$ deeper and $\sim 70 \mathrm{~m}$ thick, a low resistivity response in the sandy beds suggests a potential gas-charged interval beneath the gas hydrate stability field. The logging data indicate that the BSR is a response to both a small velocity 
high from hydrate cement in the hydrate stability zone and a more significant velocity low caused by the presence of uncemented sediments and/or free gas below the stability field.

Ongoing log analysis will quantify the amount of pore space charged with hydrate in the zone above the BSR and, integrated with 3-D seismic analysis, the total amount of gas in this region of the Kumano Basin section. During Expedition 316, Site C0002 was cored late in the expedition as a contingency operation. The BSR interval and overlying apparent gas hydrate-rich zone was deliberately not cored in order to allow time for deeper objectives, so core-based sampling of the zone awaits future drilling.

\section{Conclusion}

Overlapping sites and objectives were drilled on the three expeditions comprising NanTroSEIZE Stage 1. Because specific teams of specialists were onboard and collaborated on core and log analysis during each separate expedition, the site reports are, by necessity, published separately in this volume. This introduction and summary of some of the results highlights a few overarching aspects of the drilling results. Taken as a whole, the NanTroSEIZE Stage 1 transect of six major sites has documented the structure, sedimentology, tectonic history, present-day stress conditions, and other aspects of the margin. The overall principal goal of characterizing the fault systems and their wall rocks in the aseismic regime and sampling the older prism beneath the Kumano forearc basin has been achieved, setting the stage for deep riser drilling to the seismogenic zone.

\section{References}

Baba, T., Cummins, P.R., Hori, T., and Kaneda, Y., 2006. High precision slip distribution of the 1944 Tonankai earthquake inferred from tsunami waveforms: possible slip on a splay fault. Tectonophysics, 426(1-2):119-134. doi:10.1016/j.tecto.2006.02.015

Dugan, B., and Flemings, P.B., 2000. Overpressure and fluid flow in the New Jersey Continental slope: implications for slope failure and cold seeps. Science, 289(5477):288-291. doi:10.1126/science.289.5477.288

Heki, K., 2007. Secular, transient and seasonal crustal movements in Japan from a dense GPS array: implication for plate dynamics in convergent boundaries. In Dixon, T., and Moore, C. (Eds.), The Seismogenic Zone of
Subduction Thrust Faults: New York (Columbia Univ. Press), 512-539.

Hyndman, R.D., Wang, K., and Yamano, M., 1995. Thermal constraints on the seismogenic portion of the southwestern Japan subduction thrust. J. Geophys. Res., [Solid Earth], 100(B8):15373-15392. doi:10.1029/ 95JB00153

Kinoshita, M., Kanamatsu, T., Kawamura, K., Sibata, T., Hamamoto, H., and Fujino, K., 2008. Heat flow distribution on the floor of Nankai Trough off Kumano and implications for the geothermal regime of subducting sediments. JAMSTEC Deep-Sea Res., 8:13-28.

Kinoshita, M., Moore, G., von Huene, R., Tobin, H., and Ranero, C.R., 2006. The seismogenic zone experiment. In Burger, R., and Fujioka, K. (Eds.), The Impact of the Ocean Drilling Program. Oceanography, 19(4):28-38.

Moore, G.F., Bangs, N.L., Taira, A., Kuramoto, S., Pangborn, E., and Tobin, H.J., 2007. Three-dimensional splay fault geometry and implications for tsunami generation. Science, 318(5853):1128-1131. doi:10.1126/science. 1147195

Moore, G.F., Taira, A., Klaus, A., et al., 2001. Proc. ODP, Init. Repts., 190: College Station, TX (Ocean Drilling Program). doi:10.2973/odp.proc.ir.190.2001

Park, J.-O., Tsuru, T., Kodaira, S., Cummins, P.R., and Kaneda, Y., 2002. Splay fault branching along the Nankai subduction zone. Science, 297(5584):1157-1160. doi:10.1126/science.1074111

Screaton, E., Saffer, D., Henry, P., and Hunze, S., 2002. Porosity loss within the underthrust sediments of the Nankai accretionary complex: implications for overpressures. Geology, 30(1):19-22. doi:10.1130/00917613(2002)030<0019:PLWTUS>2.0.CO;2

Seno, T., Stein, S., and Gripp, A.E., 1993. A model for the motion of the Philippine Sea Plate consistent with NUVEL-1 and geological data. J. Geophys. Res., 98(B10):17941-17948. doi:10.1029/93JB00782

Tobin, H.J., and Kinoshita, M., 2006a. Investigations of seismogenesis at the Nankai Trough, Japan. IODP Sci. Prosp., NanTroSEIZE Stage 1. doi:10.2204/ iodp.sp.nantroseize 1.2006

Tobin, H.J., and Kinoshita, M., 2006b. NanTroSEIZE: the IODP Nankai Trough Seismogenic Zone Experiment. Sci. Drill., 2:23-27. doi:10.2204/iodp.sd.2.06.2006

Zoback, M.D., Barton, C.A., Brudy, M., Castillo, D.A., Finkbeiner, T., Grollimund, B.R., Moos, D.B., Peska, P., Ward, C.D., and Wiprut, D.J., 2003. Determination of stress orientation and magnitude in deep wells. Int. J. Rock Mech. Min. Sci., 40(7-8):1049-1076. doi:10.1016/ j.ijrmms.2003.07.001

Initial receipt: 16 January 2009

Acceptance: 9 February 2009

Publication: 11 March 2009

MS 314315316-101 
Figure F1. Location of sites drilled during the three expeditions of NanTroSEIZE Stage 1 (red circles) in the Nankai Trough off Kumano, Japan. Black box = location of the 2006 3-D seismic survey, black line = arbitrary line extracted from 3-D seismic volume (Fig. F3), yellow arrows = computed far-field convergence vectors between Philippine Sea plate and Japan (Seno et al., 1993; Heki, 2007). Stars = epicentral location of great earthquakes. Inset shows location of Nankai Trough.

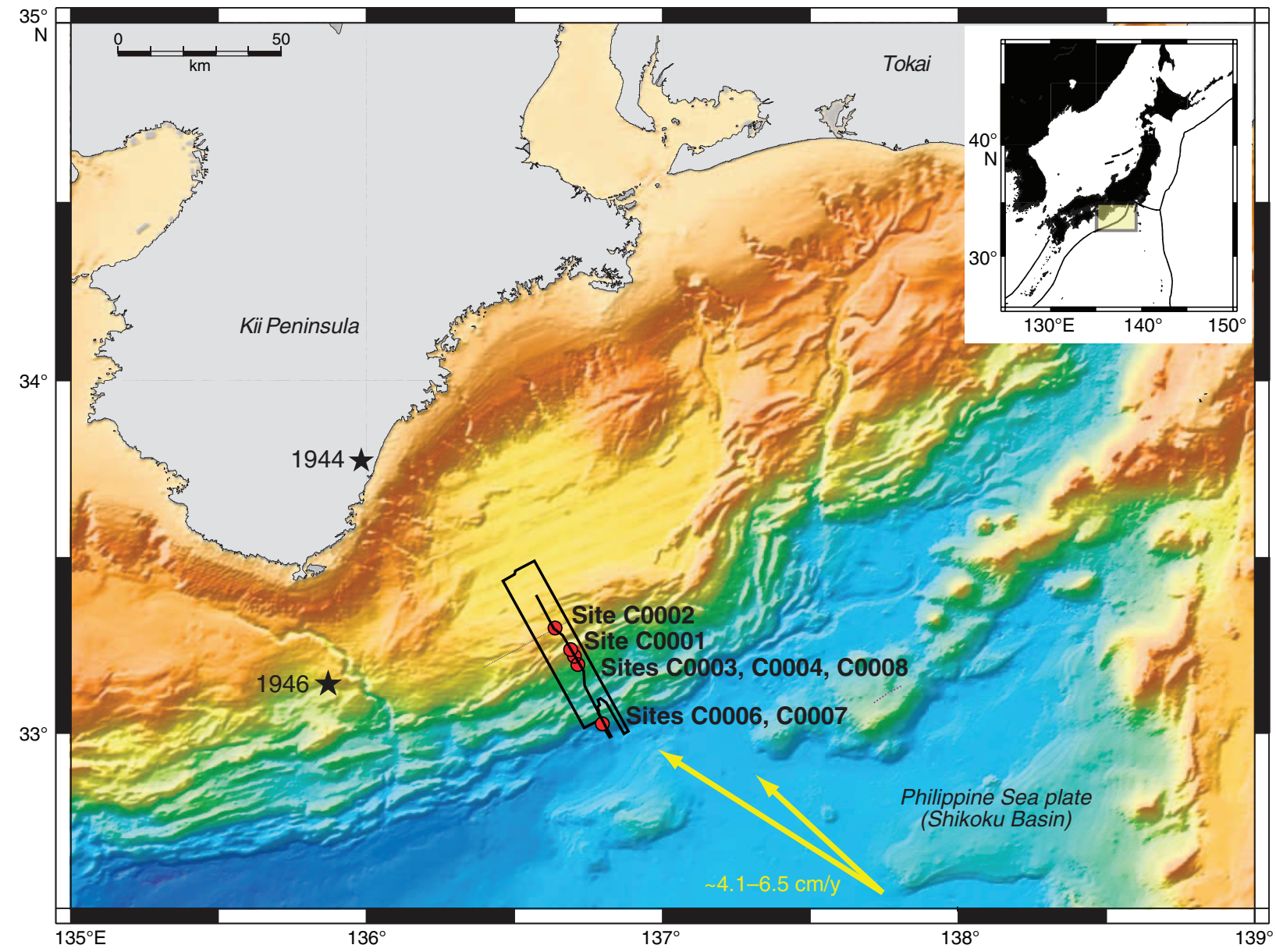


Figure F2. Regional long seismic reflection depth line (after Park et al., 2002) with drilled NanTRoSEIZE Stage 1 sites (solid colored lines with site labels), planned later deep riser sites (unfilled transparent lines), and major interpreted tectonic features.

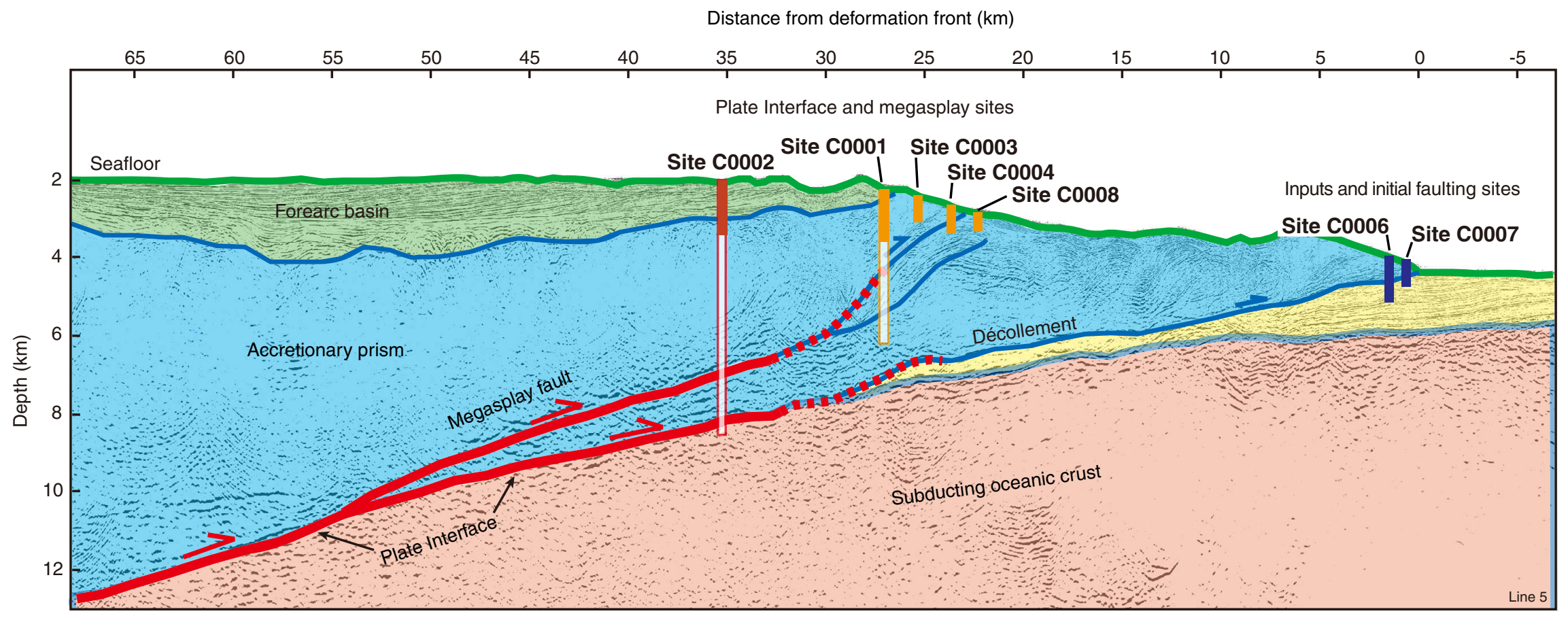


Figure F3. Composite seismic line extracted from 3-D seismic volume, reproduced from Moore et al. The line crosses through (or near) all Stage 1 drill sites (Fig. F1). A. Uninterpreted depth section processed with prestack depth migration. B. Interpreted version of A. Only a few representative faults are shown. Dashed lines = less certain fault locations. Morpho-tectonic zones are shown between the two sections. KBEFZ $=$ Kumano Basin edge fault zone, PTZ = protothrust zone, BSR = bottom-simulating reflection, $\mathrm{VE}=$ vertical exaggeration.

A
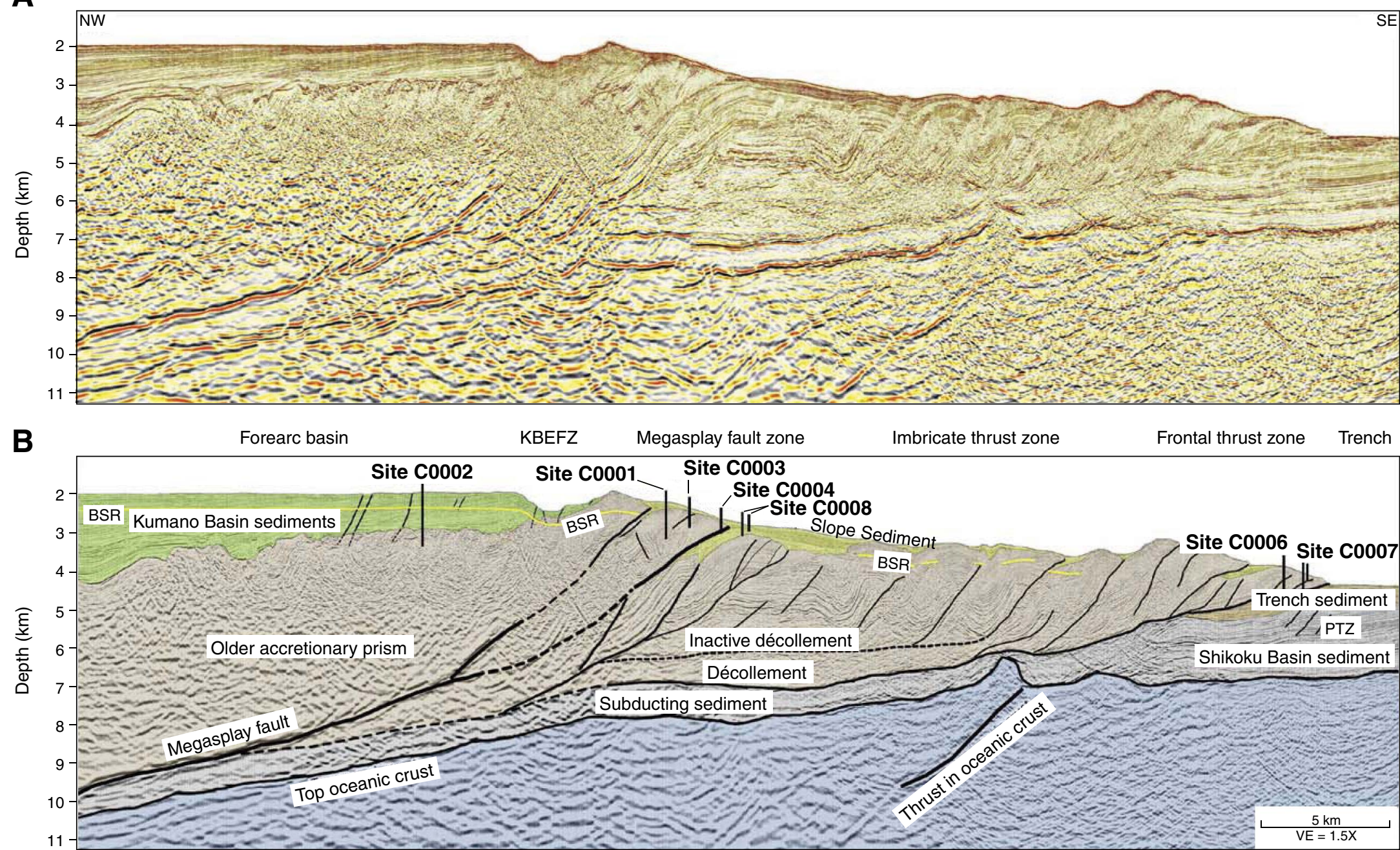
Figure F4. Inline seismic section for the frontal thrust region, Sites C0006 and C0007 (reproduced from Moore et al.). USB = upper Shikoku Basin facies sediment package.

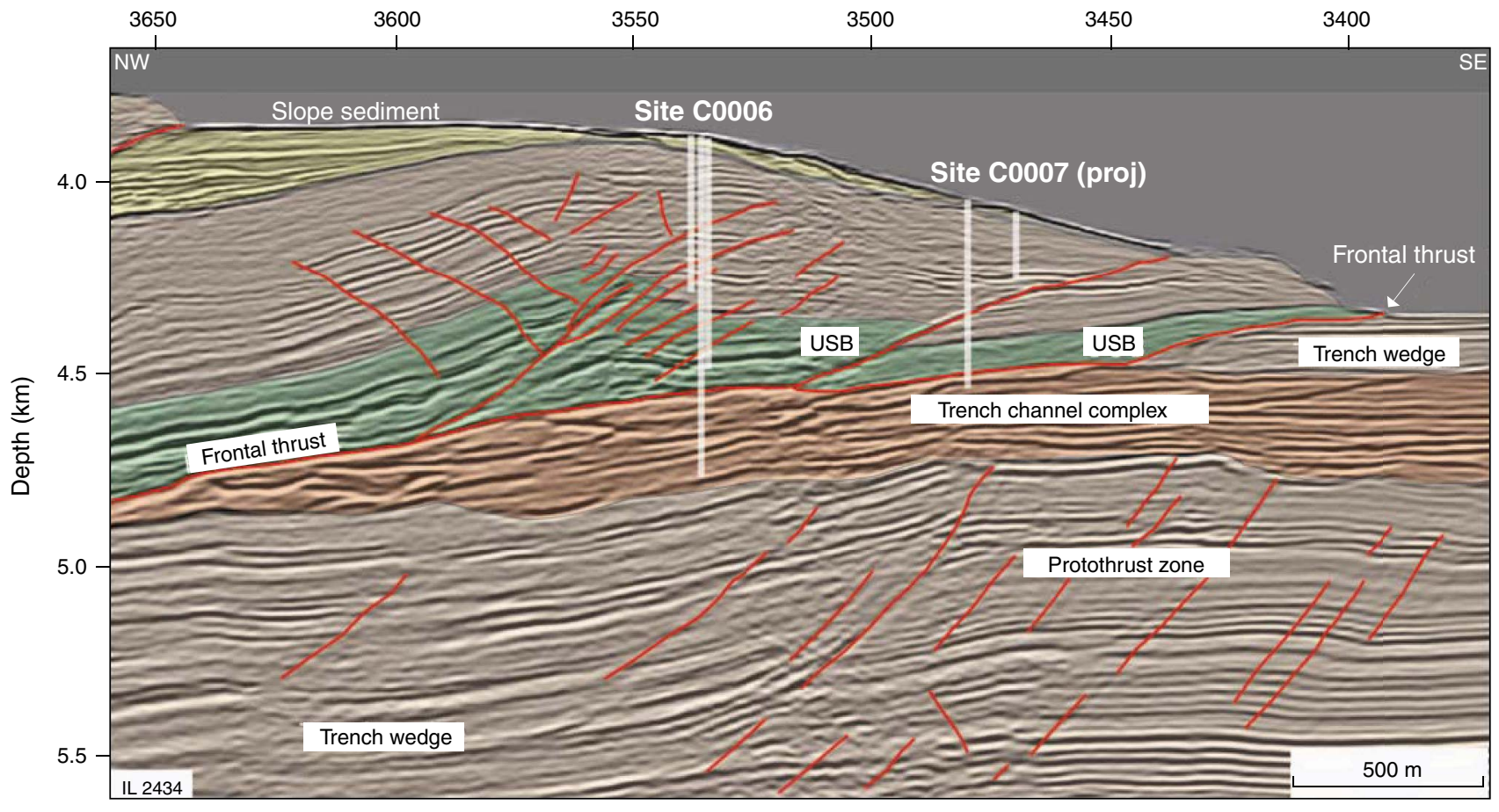


Figure F5. Fault core examples from the frontal thrust region, Site C0007 (interval 316-C0007D-29R-2, 37-73 $\mathrm{cm}$ ). Appearance of concentrated deformation in lower portion of frontal thrust fault Zone 3 (438 mbsf). A. Xray image. B. Photograph of finely brecciated hemipelagic mudstone. C. Close-up of finely brecciated interval. D. Thin ( $2 \mathrm{~mm}$ thick) dark layer (arrow) developed at base of finely brecciated interval.
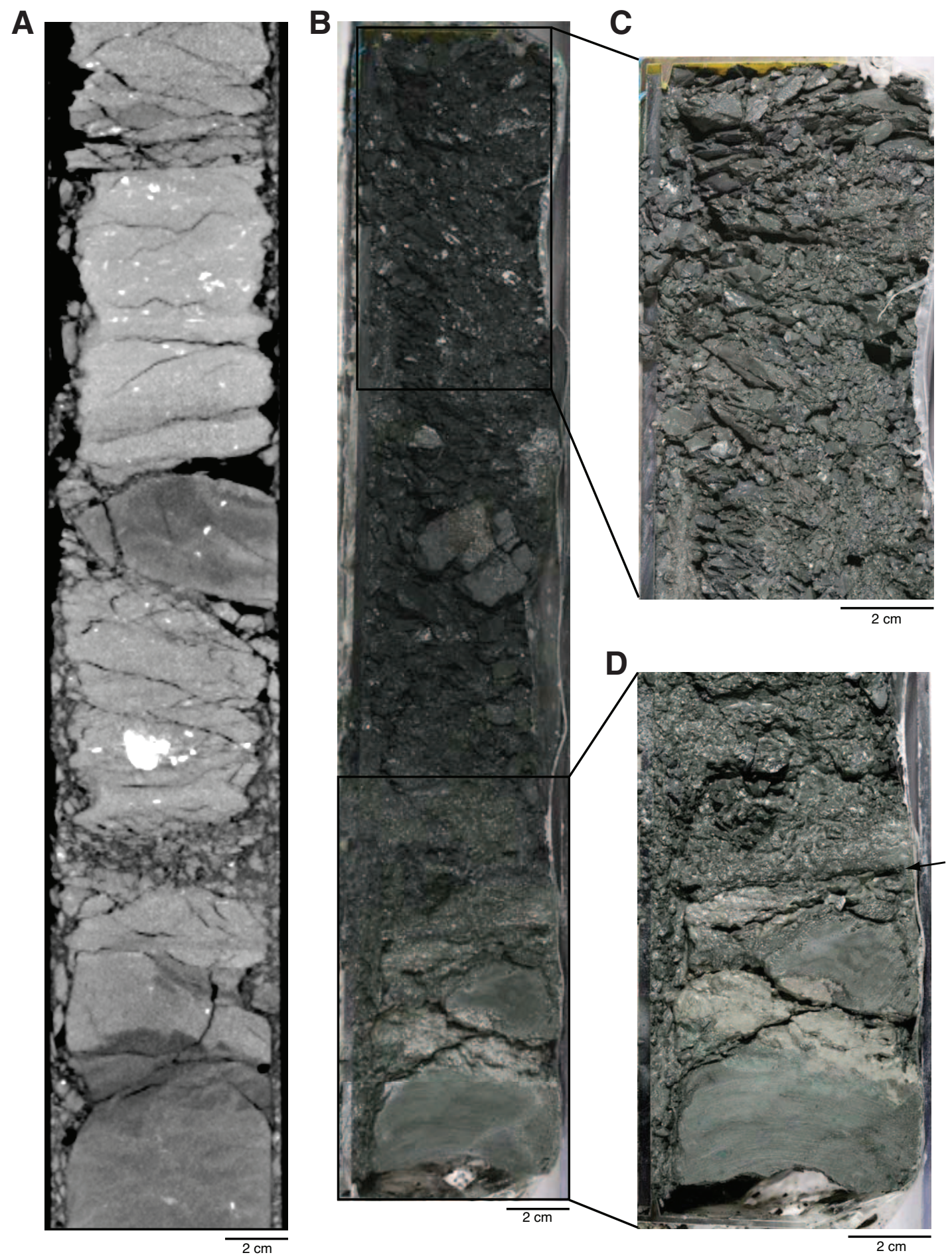
Figure F6. Inline prestack density migrated seismic section through the megasplay fault thrust sheet sites showing total drilled depth at each site. Age labels show maximum sediment depositional ages based on nannofossil biostratigraphy. $\mathrm{VE}=$ vertical exaggeration.

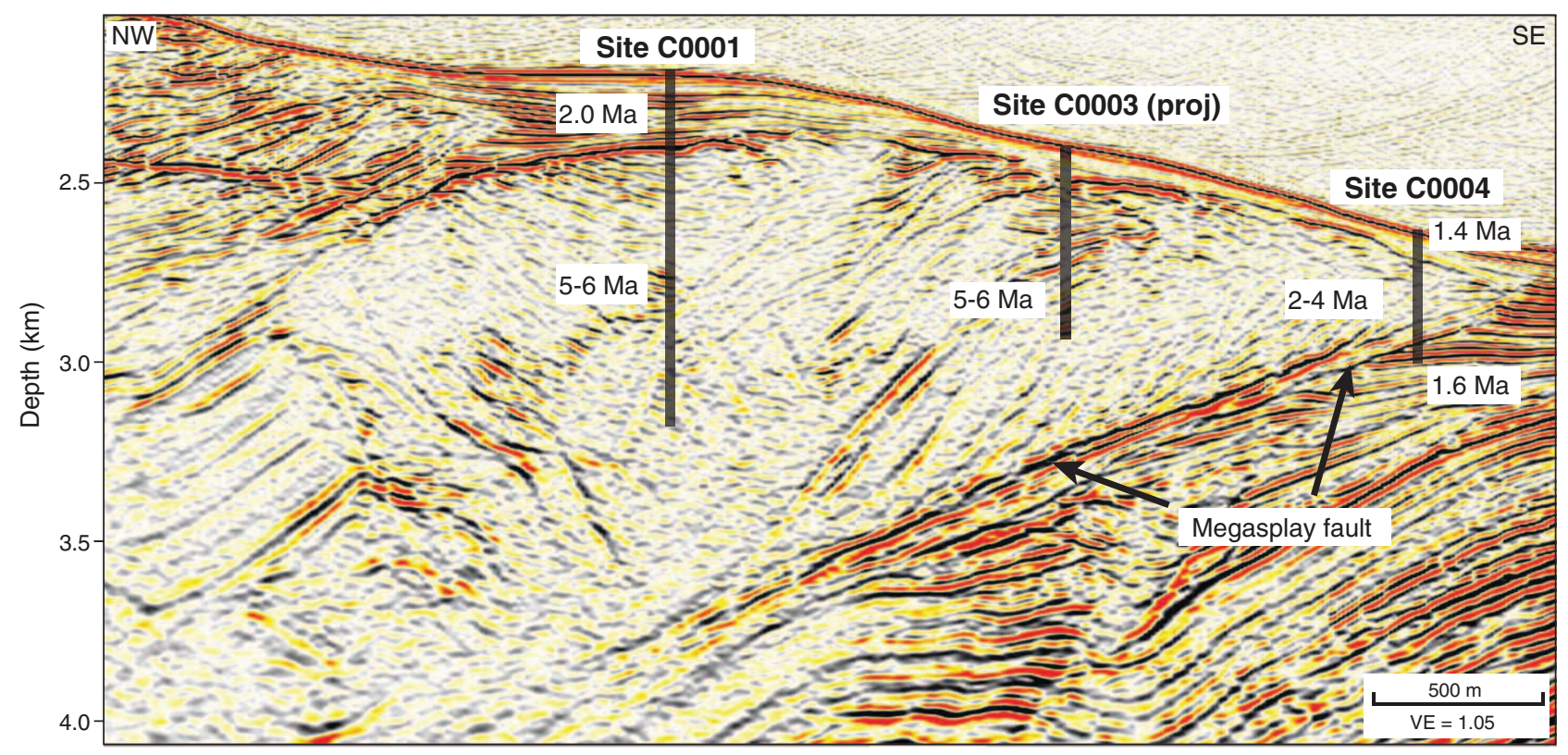


Figure F7. Inline 2596, Site C0003. Black line = originally planned total depth of $1000 \mathrm{mbsf}$, green line $=$ actual depth achieved when the drill string became stuck, yellow line = approximate length of stuck bottom-hole assembly equipment. The reflector that intersects the borehole at $\sim 2.9$ $\mathrm{km}$ depth is interpreted as a fault zone and is the probable source of dated cavings of late Miocene age in the hole. VE $=$ vertical exaggeration.

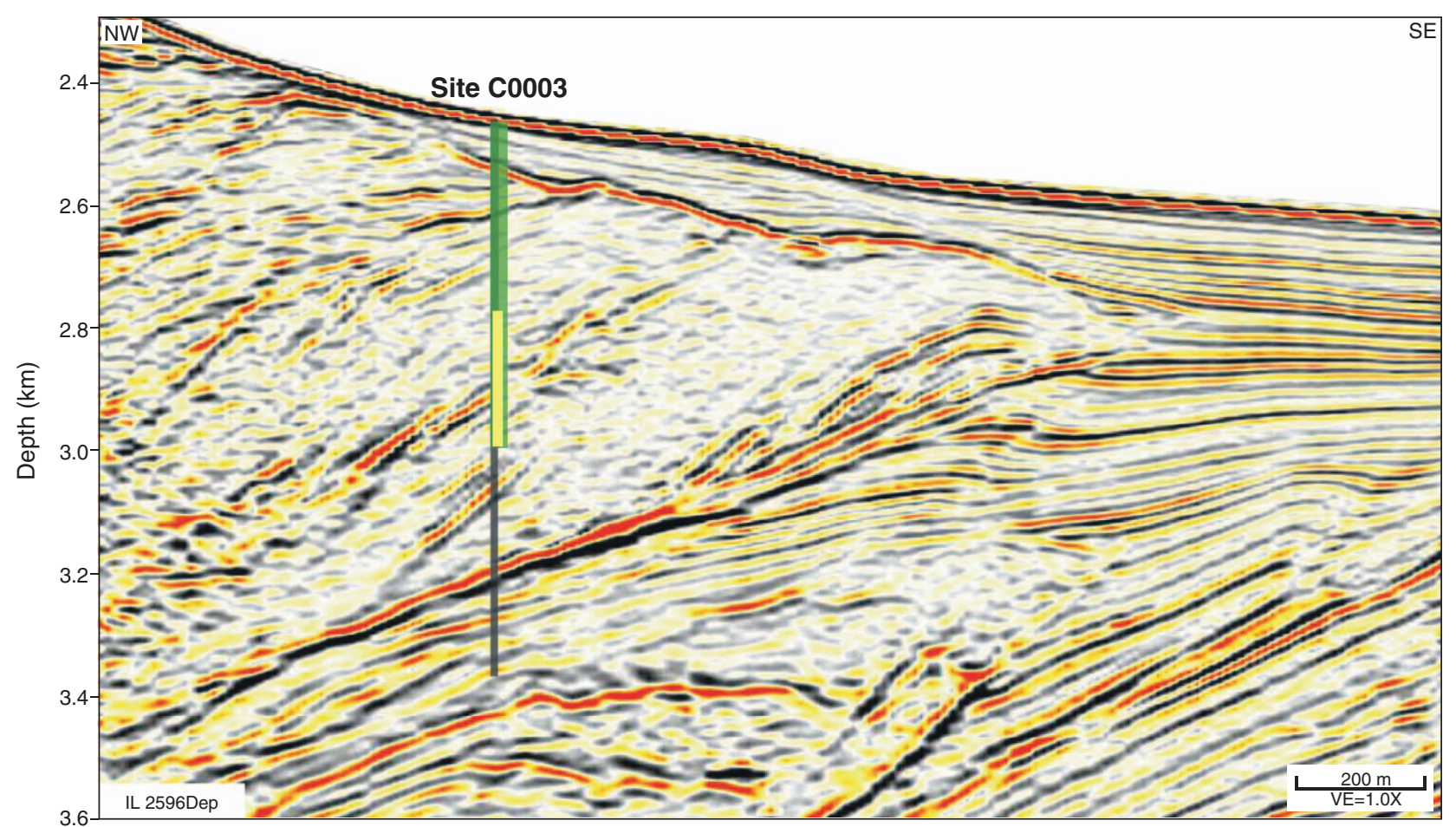


Figure F8. Resistivity-at-the-bit images synoptically showing full depth extent of LWD intervals, Sites C0001, C0002, C0004, and C0006. Vertical paired dark bands are images of borehole breakouts that have been interpreted in order to generate the average $S_{\mathrm{Hmax}}$ azimuths shown in Figure F9. LSF $=$ LWD depth below seafloor.

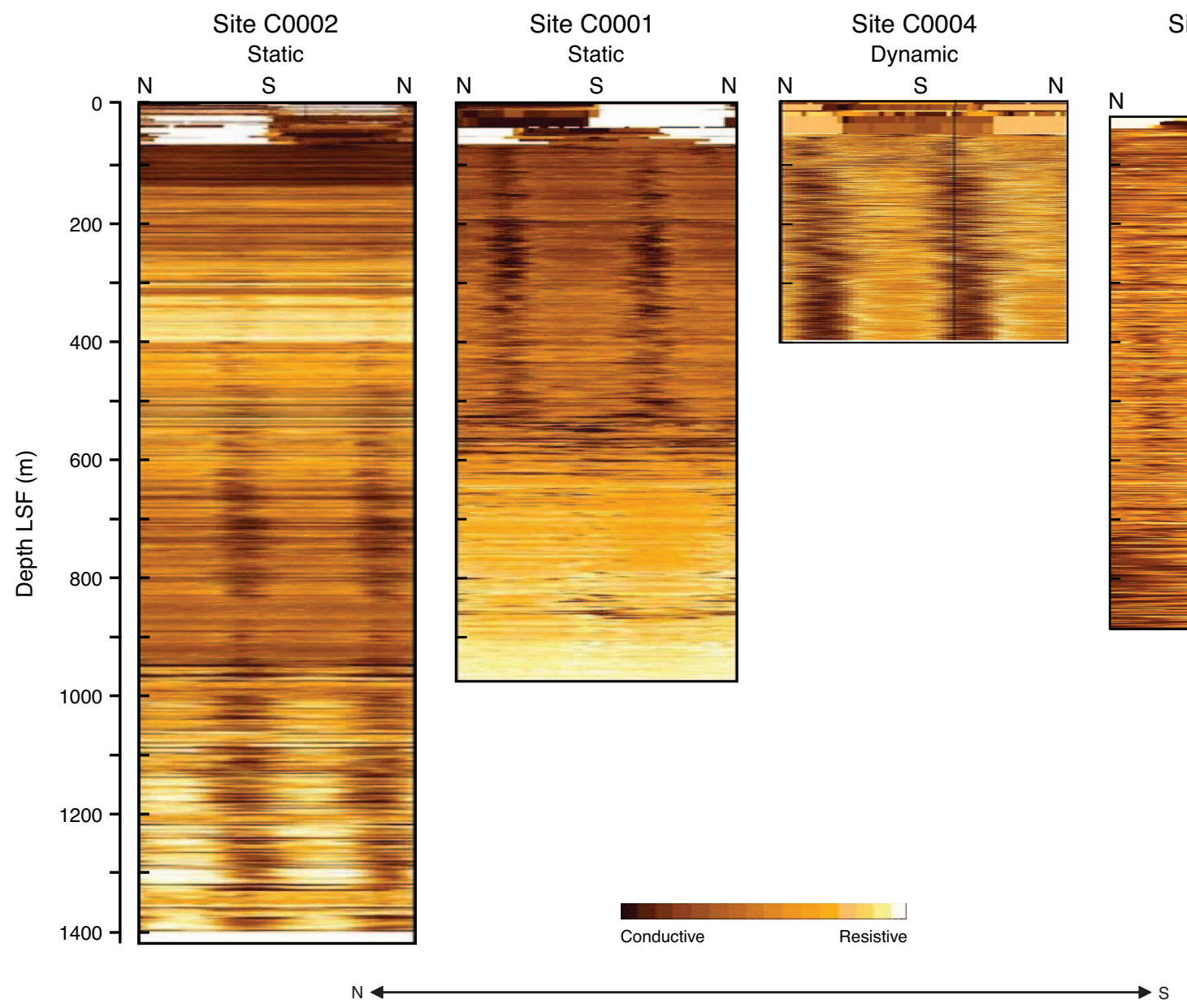

Site C0006

Dynamic

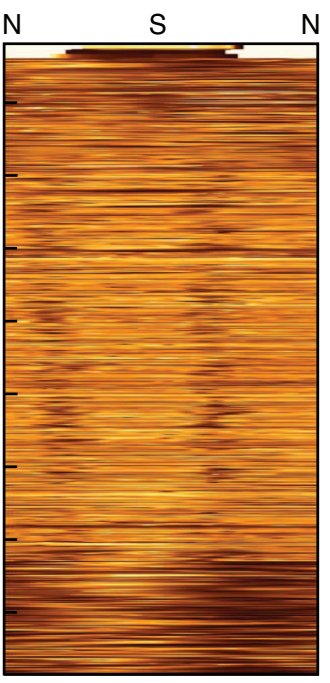


Figure F9. Azimuth of maximum horizontal stress (red lines) estimated from borehole breakout images, Sites C0001, C0002 (in basin above $936 \mathrm{mbsf}$ ), C0004, and C0006. Blue line = estimate for older accretionary prism formation below $936 \mathrm{mbsf}$ at Site C0002, yellow arrows = computed far-field convergence vectors between Philippine Sea plate and Japan (Seno et al., 1993; Heki, 2007). GPS = Global Positioning System.

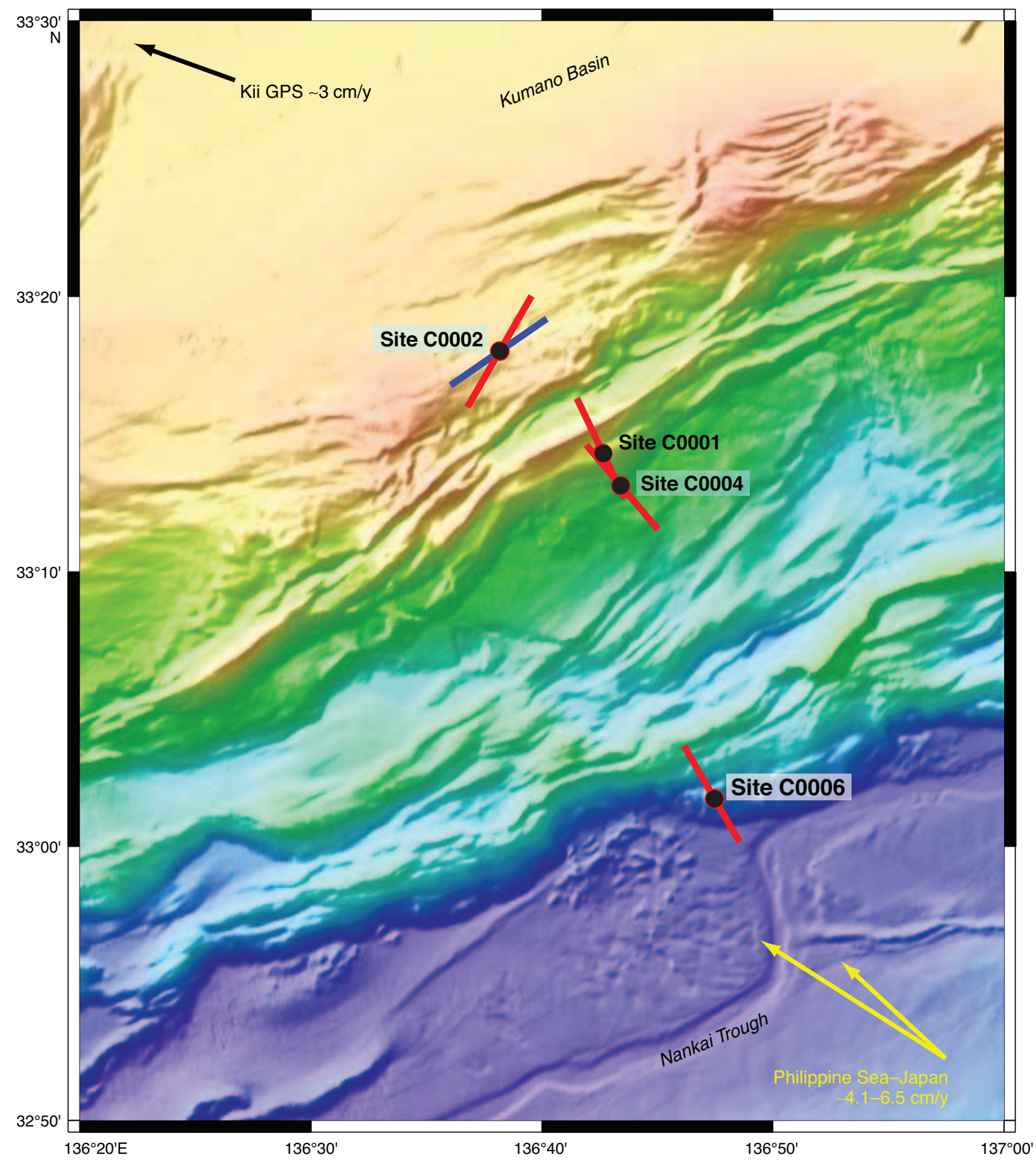

